\title{
Reproduction of Batak Manuscript for the Purposes of Revitalizing Local and Commercial Wisdom in Samosir Regency, North Sumatera Province
}

\author{
Warisman Sinaga ${ }^{1}$, Ramlan Damanik ${ }^{2}$ \\ ${ }^{1,2}$ Faculty of Humanities, Universitas Sumatera Utara, Indonesia \\ warisman@usu.ac.id
}

\begin{abstract}
Pustaha laklak is a handscrift or manuscript from Batak that uses tree bark as its medium. The writing in this pustaha laklak uses Batak script or also called the Batak letter. Batak letter has special technicalities in its writing. And this writing system is also closely related to the culture and local wisdom of Batak people. The relationship between the Batak script and the Batak customs is too close, so that efforts to obtain and possess these old texts continue to be carried out. One of the efforts undertaken by the community in Samosir Regency is to copy back the old manuscripts. This activity is part of the reproduction of the manuscript. However, this copying activity was carried out not solely for the purpose of saving the manuscript. However, commercial interests tend to be motivated because the texts are traded as souvenirs for local and foreign tourists. The right approach taken in this study is the approach of philology and local wisdom. Djamaris (2002: 3) said that philology is a science that makes old texts as the object of writing. Manuscript reproduction is an object of philology while the text or all messages contained in the manuscript is a form of local wisdom of the Toba Batak people. The research method used is the single manuscript edition method. Tomok Village and Tuktuk Siadong Village are suitable locations to be used as research sites because these two villages are closely related to the reproduction of manuscripts for commercial purposes for local and foreign tourists. Based on the studies conducted, it can be seen that copying is always done. Every writing of a manuscript, the writer refers to the manuscript that becomes the reference. The copying process is according to requests from what people need. The mistake that tends to be made is the use of child letter and parent letter, especially for child letter / $i$ / and / $u$ /.
\end{abstract}

Keywords

reproduction; script;

commercial; revitalization

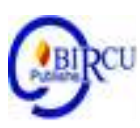

\section{Introduction}

Pustaha Batak is also known as a bark book. Pustaha Batak (Toba) has pages or sheets that are long and bent to form sheets like books. This library was not only made of bark, but some were written on bamboo and bones. Pustaha that written on the bark called pustaha laklak. The wood used to make pustaha is a type of tree called by the Batak community is alim tree or hau alim. Pustaha laklak has characteristics and high meaning for the community. The characteristics can be known from the material or the base of the manuscript, the process of making, the characters as symbols of sound, language, and the contents or thoughts recorded in it, while the meaning can be known from the thoughts that contained which hold on and view of life. 
According to Teygeler (1995) the making of pustaha through several steps, namely (1) alim tree trunks are cut, then the skin is taken. Cut the length and width of the skin is adjusted to the needs. (2) Then the bark is dried. (3) The surface of the bark that has been dried and then smoothed with a certain tool, a knife and a kind of leaf called Latin ficus empelas. (4) After the bark is smooth and thin like paper, the pustaha is bent and the size also depends on the author. (5) the library is ready to be written and the writing system starts from left to right. The making of the library is still ongoing, especially in the Toba Batak people who live in Tomok, Samosir Island. We know that Samosir as one of the districts is in a potential position in tourism development. This is behind the vision of Samosir Regency as a beautiful, peaceful and cultured 2010 Tourism District. (Sitanggang, 2008: 222).

As a tourist destination (DTW), Samosir Regency continues to attract the tourists. And one of its attractions is by offering a variety of souvenir products that describe the natural wealth and culture of the local community. Even one of the high-value cultural products, such as pustaha laklak, is offered and made as a souvenir product. This will have a positive impact on retention of the Batak script. However, the tradition of copying in this area still needs attention.

The function of the pustaha laklak has changed, no longer as a recorder of knowledge written by teachers and shamans, but it written by ordinary people whose purpose for souvenir items. Against this commercial interest, the writing (reproduction) of this manuscript contains many shortcomings. This is what underlies this writing in order to revitalize or revive the creation and use of the Batak script in the manuscript (pustaha laklak).

Revitalization activities in this writing are associated with philological activities, namely copying back the text by paying attention to the reference text. Revitalization is a process or method and act to revive any activities. Revitalization means making something or an action vital. Vital words can be interpreted as very important or very necessary for life and so on.

This is done so that there are no irregularities in the derivative text (copy). Manuscripts as a copies will be considered whether they have been written with the appropriate script, language, and text. Forms of error will be shown so that the error is not repeated in subsequent copying activities. The mistakes in the tradition of re-copying are more focused on errors in the use of this letter and child letter. Because, if there is an error in the use of both, the meaning will be error. This is so fateful, especially for people who are unfamiliar with the script even though the text is used as a reference for learning.

\section{Review of Literatures}

Etymologically, the word of philology is formed from two words namely philos and logos. The word of philology (Greek) can mean 'love words'; 'happy to say '. The meaning of this word develops into 'happy learning; happy science; happy literature, or happy culture. 'And finally philology is defined as a knowledge of literature that covers the fields of language, literature, and culture (Hasjim, 1985: 1).

Djamaris (2002: 3) says that philology is a science that makes old texts as the object of writing. And finally, philology is interpreted as a science that talks about old literary works and other written sources.

One of philology activities is a copying. Muliono, et al. (1985: 59) said that the sequence of inheritance that passed on by a hereditary text is called tradition. Manuscripts are reproduced because people want to have their own manuscripts. Maybe because the original manuscript has been damaged by time; or because there is a concern that something is 
happening with the original text, for example lost, burned, spilled liquid objects, because of war or just because of displacement. That manuscripts are considered important will be copied back with various objectives, for example political, religious, educational, and even commercial purposes (for sale).

In this copying activity, it is possible that mistakes or changes will occur. This can be caused by the copyist not understanding the language and writing in that script, or because of lack of light, misread, or also because of the inaccuracy of the copyer so that some letters are missing. In philology activities it is called haplology and haplography.

\subsection{The Meaning of the Script}

Djamaris (2002: 3) said that manuscripts are all handwritten material left by our ancestors on paper, papyrus, bark, and rattan.

The manuscript is also called handscrift or manuscript, which is a handwriting that stores various expressions of thoughts and feelings as a result of past national culture (Hasjim, 1985: 54).

Batak manuscripts are written using scripts consisting of two functions, namely as a parent letter and a child letter. The parent letters and child letter called as indung ni letter which amounts to 19 letters, so the Batak people called them with sampulusia and anak ni letter which consists of 6 forms with different functions.

\subsection{The Meaning of the Text}

Text is the content of the script; the contents of manuscripts that are abstract and only can be imagined (Baried, 1985: 56). The actual text is the content, which is in the form of ideas or mandates that will be conveyed by the author to the reader. While the form is a story in the text that can be read and studied. This can be learned based on an intrinsic approach in the form of plot, characterization, characterization, setting, language style, and so on. In general, the text is copied back based on certain objectives, namely: a) want to have a script; b) the original text has been corrupted and cannot be read; c) worry that something will happen to the script.

The working of this philology are based on the principle that the text changes in its transmission, so that various texts appear. So, philology works because of variations in the text. In copying activities, the appearance of variations must be avoided because it can cause errors in the delivery of the text. If the text changes, the information in the text will also change and will be further from the original.

Text variations can occur due to:

1. Error in copying;

2. Unreadable text;

3. Texts are missing or changed;

4. Language conventions used in inappropriate texts;

5. Different story sequences;

6. Humans (copying, caring, and subjectivity);

7. Non-durable material; and

8. Weather, including air temperature.

In philology, variations of text are considered an error (corrupt) that must be cleaned. The appearance of textual variations shows that the decline or copying done by humans results in an unfaithful form of copying. Thus steps of philological activities in the reproduction of the texts. 


\subsection{Local Wisdom}

Local wisdom is a local cultural value that can be used to regulate the order of people's lives wisely or wisely (Sibarani, 2012: 113). Local wisdom is a local knowledge that is created from the adaptation of a community that comes from life experiences that are communicated from generation to generation. Local wisdom is local knowledge that is used by local people to survive in an environment that is integrated with belief systems, norms, culture and is expressed in traditions and myths through oral traditions (folklore) and literary works, such as saga, lontar, chronicle, suluk, song, and so on (Gunawan, 2008).

\subsection{Purpose and Function of Local Wisdom}

Although there are efforts to inherit local wisdom from generation to generation, there is no guarantee that local wisdom will remain strong and sturdy to face the globalization which offers an increasingly pragmatic and consumptive lifestyle. Factually it can be witnessed how local wisdom laden with policies and philosophies of life is hardly implemented in increasingly pragmatic life practices. The Batak people uphold the wise words that read, Aek godang tu aek laut, dos ni roha sibaen nasaut. River water flowing into the sea, agreement (deliberation) is a way to success 'the message delivered through this wise expression is a harmony that will produce the peace.

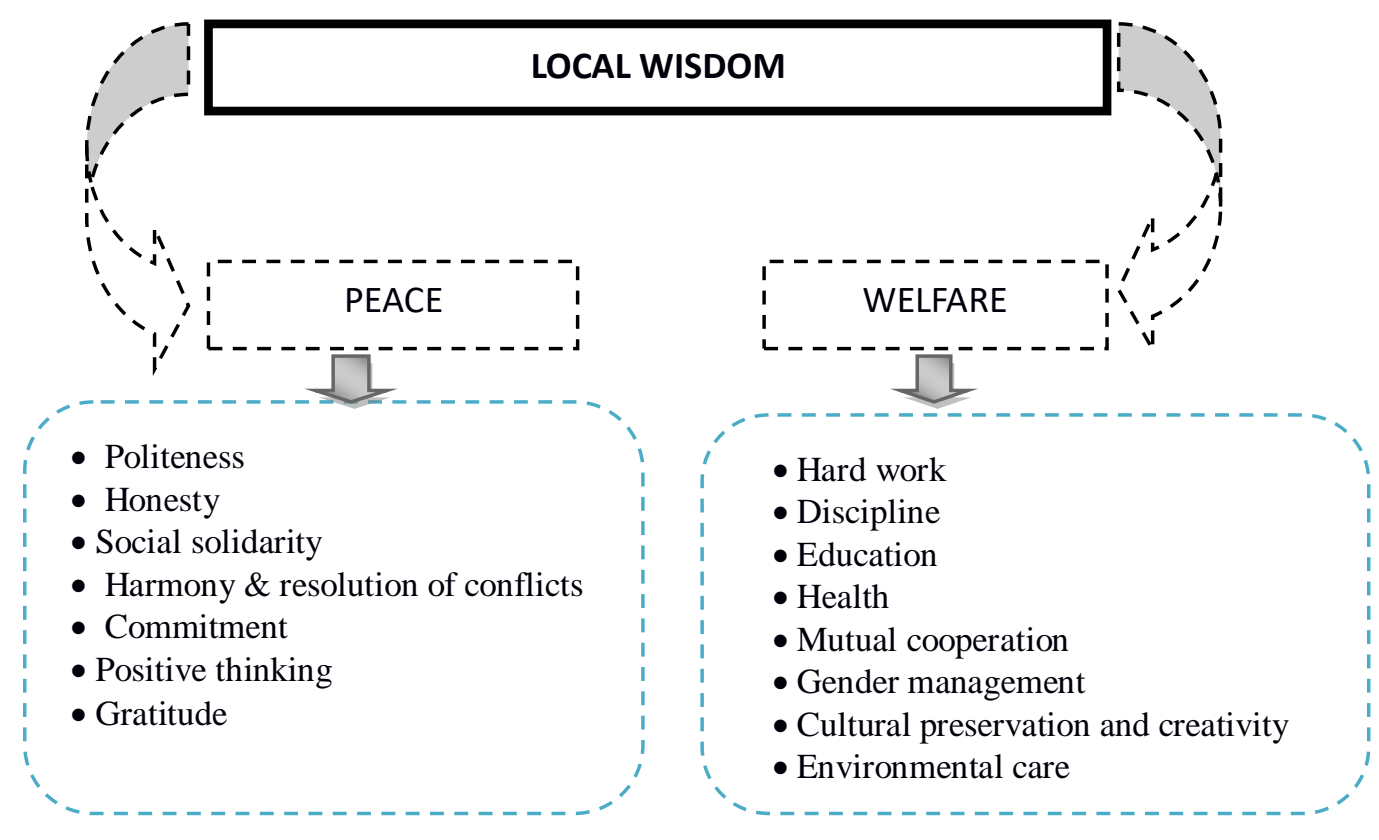

In the Toba Batak pustaha, the following proverb is often found, "sahat-sahat ni solu sai sahat ma bontean, lita hita mangolu sai sahatma tu called tu parhorasan." The meaning of this proverb is 'the boat has arrived to the pier, we wish us a long life, success, and always healthy'. The meaning contained in that proverb is everyone must have a purpose in life or commitment and must be hard worker or persistent.

These forms of local Batak wisdom are written in the pustaha laklak. Therefore, it is time to revitalize and reproduce these Toba Batak texts. The steps must be start from the preparation of the media and continue to the writing process with the Batak script. The forms of local wisdom that exist in the pustaha laklak can be in the form of folklore, warfare strategies, medication, setting days and months to start a job, and mantras, which as a whole contain moral values. In addition to the basic ingredients of bark (laklak), local wisdom is also written on bamboo media, animal bones, and other media. 


\section{Research Methods}

The method used is descriptive analytic method with the approach of philological theory and local wisdom. The views on texts and local wisdom are related to the mind of the Toba Batak people. While the data collection techniques used are:

1. Literature technique, which is looking for books as reference materials from various references so that it will be more supportive in writing.

2. Observation technique, which is directly down to the location of the writing to observe the place, the number and role of the community and souvenir merchants, as well as the behavior during the writing. Activities intended to understand more clearly the involvement of the subject of observation.

3. Interview techniques, which are techniques used to obtain further and detailed truth about the data needed. The recording technique (photo) and the note taking technique are used to get the accurate data about Batak manuscripts. In other words, this technique is useful for checking something you want to know.

And data analysis techniques performed are as follows:

1. Analyzing the basic ingredients of the Batak manuscript, such as the type, size, and other equipment used;

2. Describe the stages of Toba Batak writing;

3. Analyzing local wisdom contained in the Toba Batak manuscript which needs to be preserved and applied in daily life;

4. Collecting souvenir products which are decorated with Batak characters and traded as souvenirs from Samosir Regency; and

5. Observe the writings (characters) that used on souvenir products in the writing area based on the philological approach.

\section{Results and Discussion}

\subsection{Reproduction of Batak Manuscripts}

To arrive at the process of rewriting a manuscript, there are several activities that must be carried out, namely:

1. The selection and taking of the basic ingredients of making a library that can be in the form of bark (laklak), bamboo, animal bones, or paper.

2. Processing basic ingredients into written media.

3. Determination of the manuscript that will be used as a source of a reference for copying.

4. Preparation of materials that used for writing.

5. Writing the text as needed.

\section{a. Media for Writing Batak Manuscripts}

1. Bark

The bark commonly used for writing Batak manuscripts comes from hayu alim. This wood is also known as aloes wood (Latin: aquilaria). This type of wood is actually still commonly found in the country, but people are more familiar with the name of agar wood. Batak people call this plant by the name of hayu alim. At this time, the wood can be found in the forests of the Central Tapanuli Regency, Dairi Regency, and Asahan District.

The process of processing bark to be used as a medium is: (1) removing the outer of bark, (2) drying the bark in the sun that is not too hot, (3) peeling and taking the innermost part of the bark, and (4) smooth the bark with sandpaper so the surface of the skin looks flat and not bumpy. 


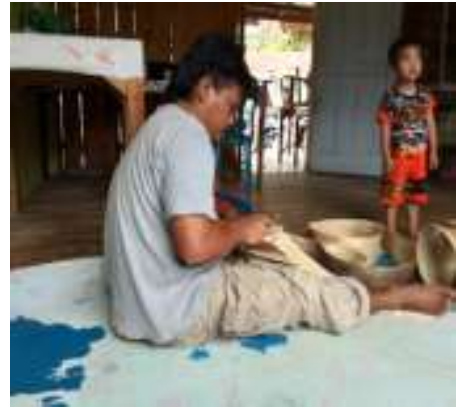

Figure 1.

Removing the outer

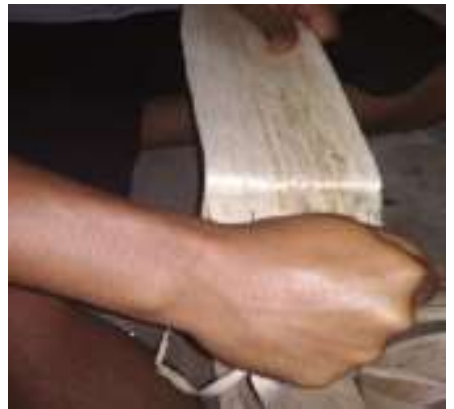

Figure 2.

Flatten the bark

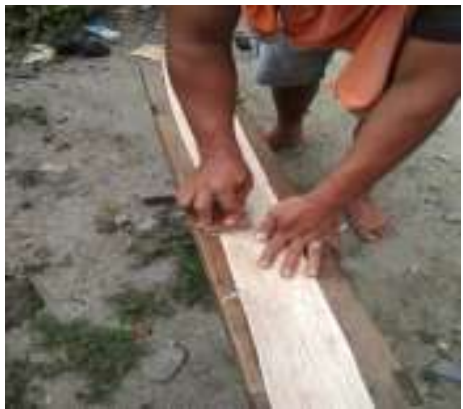

Figure 3.

Sand the bark

Remember that it is difficult to obtain agarwood of bark, the copying of old Batak manuscripts is very rare. For this reason, sometimes even poor quality bark is used to write pustaha laklak. So, in addition to the contents that are short and a little relative, then the library is not long-lasting. If you want to produce quality pustaha laklak, then the media used should be really good (dry, not squiggly, not torn).

\section{Bamboo}

Bamboo is a plant that is found in residential areas of the Batak community. The village boundaries are always marked by planting bamboo. The village will be surrounded by thick bamboo groves (Siahaan, 1982: 10).

There are 5 types of bamboo that commonly known by the Batak people. Of the five types of bamboo, for the sake of writing Batak manuscripts, Suraton feathers are used, namely bamboo in the shape of (diameter) about $5-10 \mathrm{~cm}$, thickness of $1 \mathrm{~cm}$, and an average length of $25-30 \mathrm{~cm}$. In general, the bamboo which chosen for use as a media for writing Batak manuscripts is the old bamboo but it still green. The processing of bamboo that used as a media is not as complex as the bark. The bamboo will be used through the following steps: (1) cutting the media as needed, (2) writing (can be done in conjunction with the carving motifs), (3) boiling the media that has been written, and (4) drying.

\section{Bones}

According with the observations in the field it was discovered that the bones used as media for writing Batak letters or writing the dates and directions of the cardinal directions were buffalo bones. The parts that often to use are ribs and shoulder blades (sasap). Ribs are used to write the date of Batak, while shoulder blades are used for the corners of the compass.

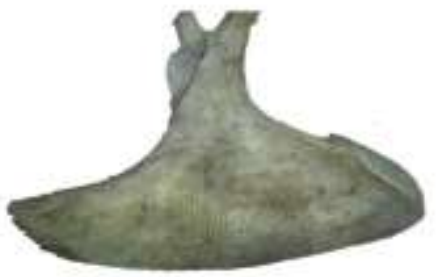

Figure 4. Shoulder Blades

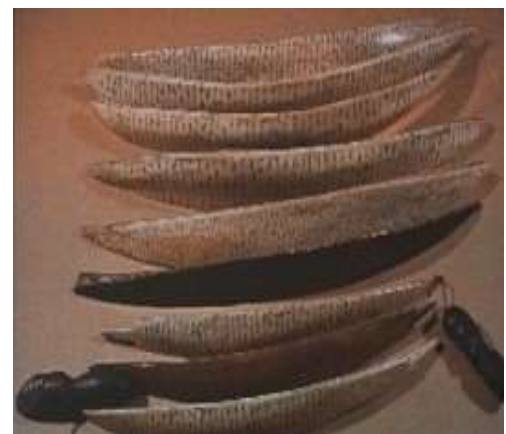

Figure 5. Ribs 
These animal bones must be cleaned using caustic soda. In ancient times lime juice was also used to clean up the craps of meat that attached the bone. The stationery which used was steel wire or bicycle spokes that had been tapered so that it was easy to use to write symbols or letters on bone media. Usually the first craving is made on a particular parts of the bone, especially on the shoulder blades.

\section{Taboo}

Batak people are among those who are always creative. There is also written text on certain fruit media, namely old pumpkins (taboos). Taboo is one of the fruits used by people in ancient times to write Batak texts. The activity of writing the manuscript to this media is carried out when the pumpkin (taboo) is not yet dried. Thus, the process of writing a script will be easier because the media is still soft. Furthermore, after the writing process is finished then the media is dried to dry. For coloring agents which used the ingredients from plants called parmagam.

The manuscripts written in this taboo media are relatively very limited in number, so this media sold out at a relatively expensive price. And from the photo above, it can be seen that these taboos are more focused on loading the dates on the Batak community and are equipped with a wind direction (na ualu village). However, to beautify the appearance of these taboos, craftsmen decorate them with various carving motifs.

\section{b. Steps to Writing the Batak Script}

1. Bark Media.

a. Make fine lines on the bark to make it easier for writers (craftsmen) to write the straight characters and look neat. The tool used to line is rollers (balobas) which made of wood, bamboo that has been cleaved. The line is usually made with a knife (panggorit).

b. Then the clean laklak measured to determine the length and width of the media to be produced.

c. Folding the laklak like an accord is then nibbling on the fold of the laklak to make it neat. If the right and left sides of the Laklak fold are not neat, then cut it using a knife so the both of sides look straight.

d. The next step is to apply the rice flour and water to the bark so that the surface of the wood is slippery and the ink is easily attached.

e. The media of Laklak is ready to be written.

f. The final step is to make the "cover". The cover is usually made of wood and bone. The cover of the Laklak is generally given a carved picture of a lizard (boraspati). While on the back, it looks plain. (W. Nainggolan, Tomok-Samosir Regency)

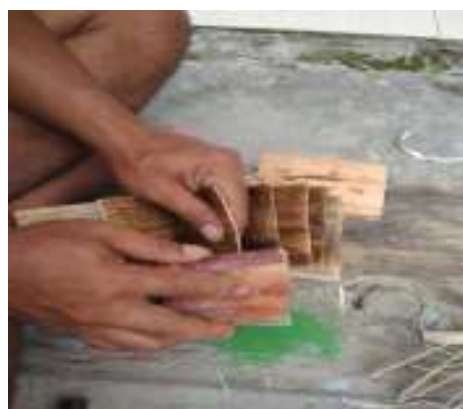

Figure 6.

Folding the Media

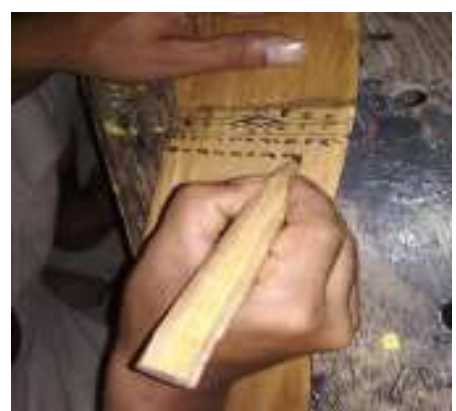

Figure 7.

Writing the Media

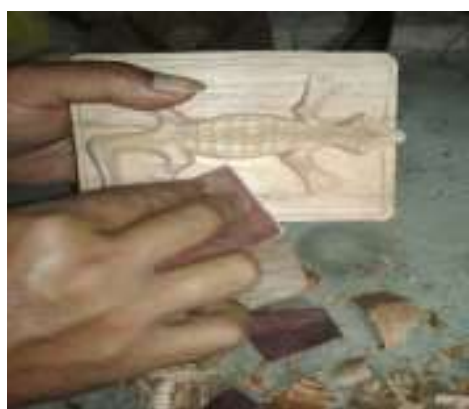

Figure 8.

Make the Cover 


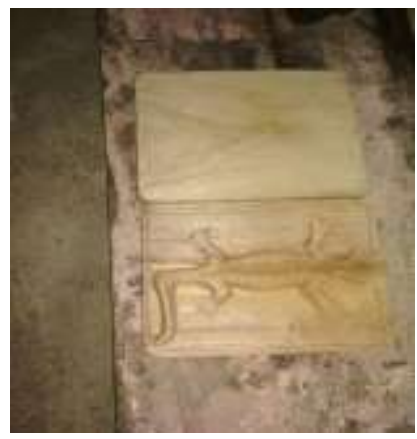

Figure 9.

Dried the Cover

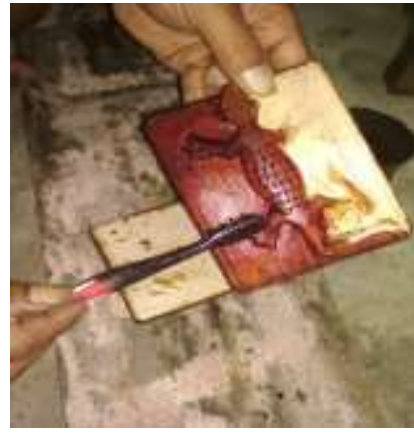

Figure 10.

Coloring the Cover

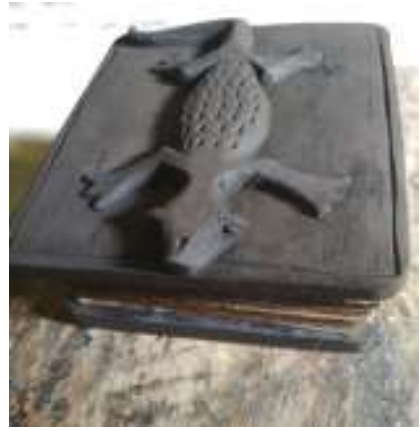

Figure 11.

Text has Done

In the past, the ink which used to write the characters on bark media was bamboo sap or orange stem sap (unte). Bamboo stems that are still green are burned and will release liquid. Thus also, the orange stems. The sap or liquid that comes out is collected in a container, which will be mixed with charcoal (agong). Candlenut is the best source of charcoal to be used as a gum mixture. Candlenut is burned to a scorch, then broken down and stirred with the liquid of gum from bamboo and orange sticks. In addition to a deeper black color, the durability of this ink is relatively longer. While the stationery used is a stick or pen that is often used by using the Chinese ink.

\section{Bamboo Media}

The process of processing bamboo into a media writing the Batak script is as follows:

1. Choosing the old bamboo;

2. Cutting bamboo, then cutting based on bamboo segments;

3. Measure and cut bamboo according to the required size;

4. Boil bamboo (so that later not eaten by termites or bamboo lice)

5. Writing the script and the appropriate motifs on bamboo, and

6. Dry bamboo.

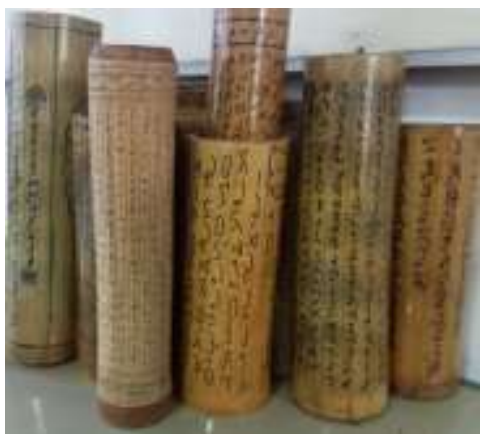

Figure 12.

Bamboo that has been writen by the Batak script

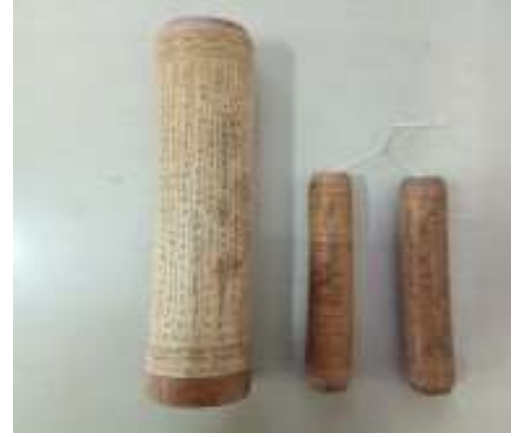

Figure 13.

Bamboo that has been writen with dates of Batak

Bamboo is an easy media to get, but it is rarely used to write the long texts because bamboo's capacity to store the text is very limited. That is why bamboo is only used for short texts, such as calendar, incantations, proverbs, and parables. Bamboo endurance is relatively the same as the other media. 


\section{Animal Bones Media}

Animal bone is one of the pustaha media which is very popular by the Batak people. In addition it has the high aesthetic of value, this media is also difficult to obtain. The stages of writing for this animal bone media are as follows.

1. Boil the animal bones to remove the remnants of meat that are still attached;

2. Drying the bones of animals that have been cleaned of the remaining meat;

3. Carving a certain part of the bone in the form of a statue of a human head and a part of bone that is longitudinally carved into a symbol of a lizard (boraspati);

4. Smooth the surface of the media by using sandpaper; and

5. Write the text to the bone media as needed. The text is usually in the form of a calendar and a wind direction (na ualu village).

6. Blackenthe text strokes with ink from the hau baja steel wood 'and now replaced with a Chinese ink.

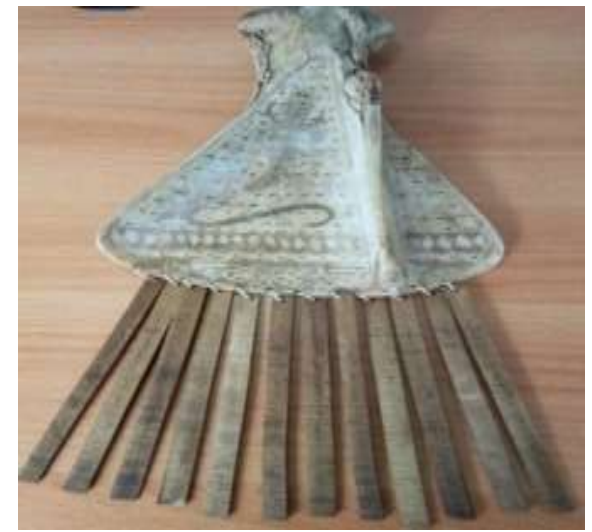

Figure 14.

Animal Bones that has been writen Batak Letter and the dates of Batak

\section{c. Mistakes Made by the Author in Reproducing the Manuscript}

There are 2 Batak manuscripts that are used as a reference to see the mistakes made by the copyist. Both of the texts do not have documentation numbers because they are not an institution document. Both texts were traded as souvenirs in Samosir District. A feature that can be made as a differentiator for both texts is the cover of the manuscript. The first manuscript uses animal bone covers, while the second manuscript uses a wooden cover.

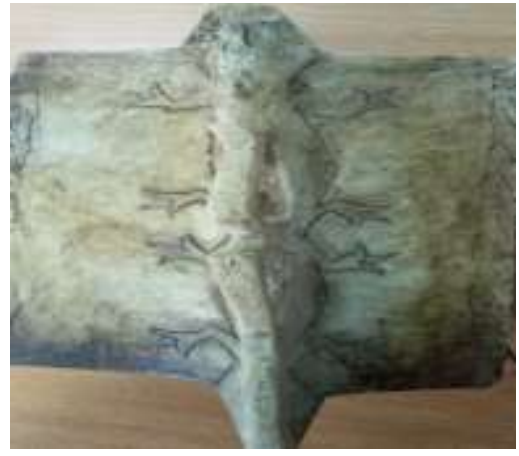

Figure 15.

Batak Manuscript with animal bone covers

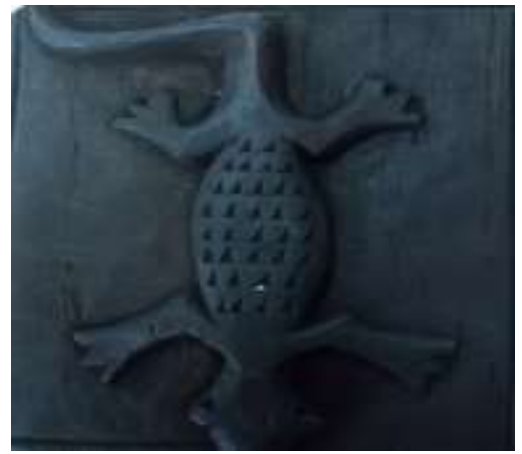

Figure 16.

Batak Manuscript with wooden cover 
d. Error Identification

Sheet 14

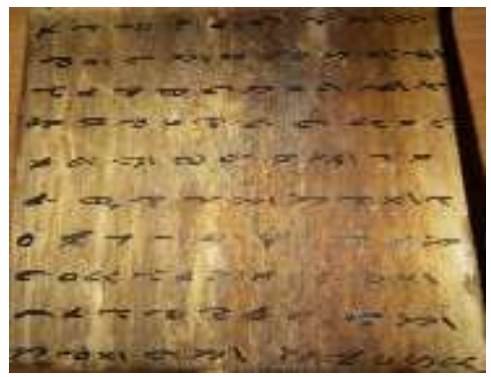

Sheet 25

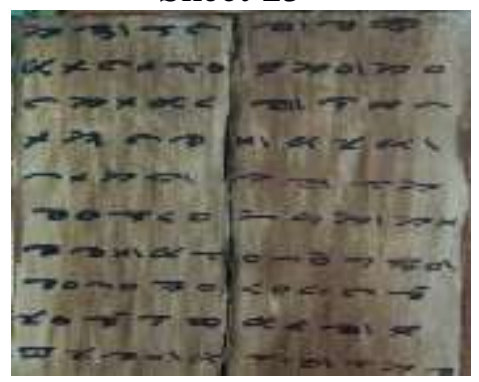

Sheet 28

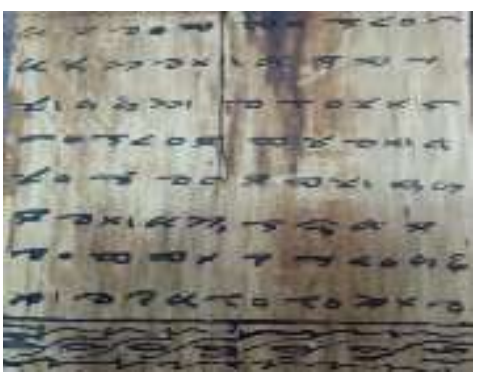

\section{Sheet 14}

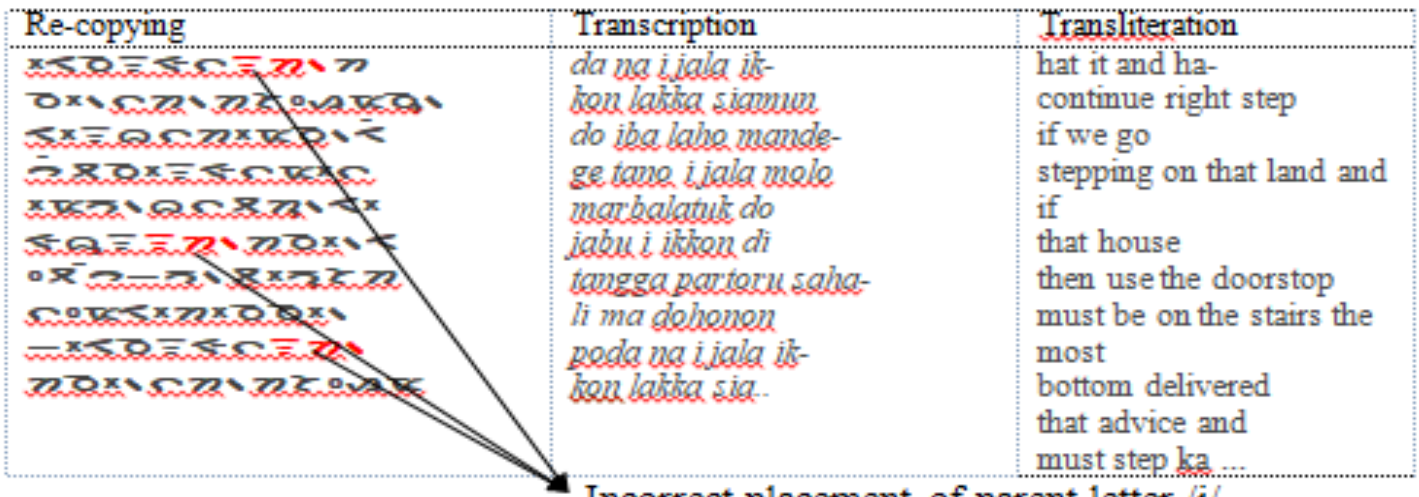

Incorrect placement of parent letter / / /

It should be written snov (ik)

\section{Sheet 25}

\section{Re-Copying}

Transcription

bundulawas:

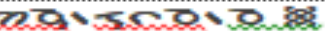

XSX $2 \times 508200420$

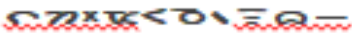

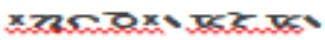

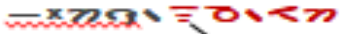

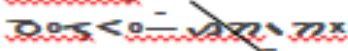

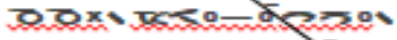

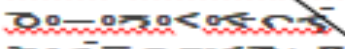

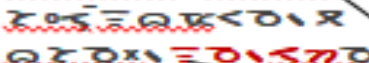

mele di tibli.

labe mansan ibe

pehulen ma som-

Beluul indahawi

duugi peakbonon

ma di pienggix

mi pirivg jalq duing

sidung i ba mangan

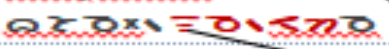

tabas on ma indaba

\begin{tabular}{|c|}
\hline Transliteration \\
\hline $\begin{array}{l}\text { his seat! } \\
\text { if at the time } \\
\text { we want to eat } \\
\text { fist to one } \\
\text { rice fist } \\
\text { then place it } \\
\text { on the edge } \\
\text { plate and } \\
\text { continue with eating } \\
\text { Recite the mantra to the rice }\end{array}$ \\
\hline
\end{tabular}

Incorrect placement of parent letter /i/

It should be written $s$ oov

(in)

\section{Sheet 28}

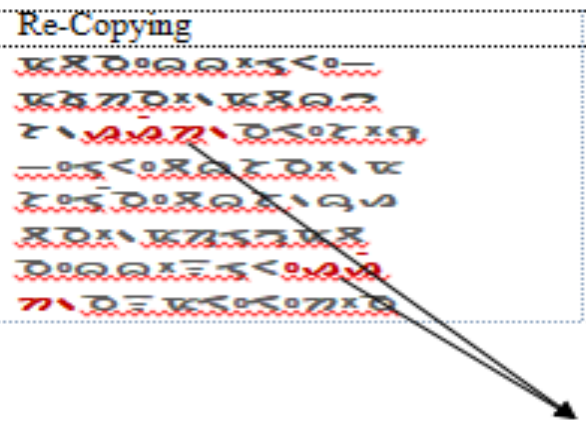

Transcription

mata ni babe suugi $12 a-$

masuhon ma th bagas.

gek na di selup is

duugi tabasen ma

sidung nitabas bug-

ton ma bus duru mata

ni babe i sungi abl

na $i$ ma didihon

Transliteration

sickle blade

then put it in

water in the quantities

then enchanted.

after that take it

out (remove) the knife

sickle it then

the water is bathed

Incorrect placement of child letter / e /

It should be written $s$ sin $\backslash(a e k)$ 
In addition the two of Batak manuscripts above, there is one type of souvenir product which is decorated with Batak letters and embellished with various engravings (gorga). The souvenir product is a pumpkin. Pumpkin fruit is very beautiful because it is filled with carvings. However, craftsmen have made many mistakes while writing Batak letters to the media. That delivered information through this media is about the parables of the Batak people, as shown below.

Based on the review of the manuscript copy (reproduction) can be identified forms of error as follows:

\begin{tabular}{|c|c|c|c|c|}
\hline \multirow[t]{2}{*}{ No. } & \multirow[t]{2}{*}{ Source } & \multicolumn{3}{|c|}{ Identification } \\
\hline & & Incorrect & Correct & Latin \\
\hline \multirow[t]{5}{*}{1.} & L. $7 /$ B. 10,11 & $z=\overline{m a}$ & $2 x=1$ & sani \\
\hline & L. 14/B. $1,6,9$ & $\overline{\bar{x}} 32 \cdot 32 \bar{x}$ & nnolnox & ikkon \\
\hline & $\begin{array}{l}\text { L. } 16 / \text { B. } 7 \\
\text { L. } 28 / \text { B. } 3,7\end{array}$ & basav & sañ & gek \\
\hline & $\begin{array}{l}\text { L. } 18 / \text { B.9 } \\
\text { L. } 20 / \text { B. } 1,2\end{array}$ & 요하. & 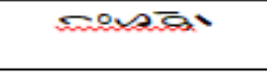 & liun \\
\hline & L. $25 /$ B. 5,10 & э๐- & 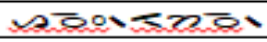 & indahan \\
\hline
\end{tabular}

Infomation: $\mathrm{L}=$ Sheet $\mathrm{B}=$ Line

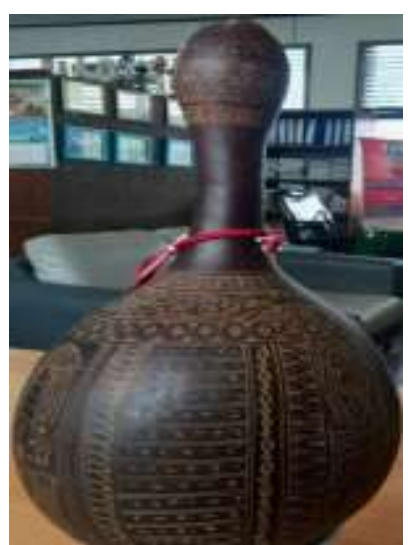

Figure 17.

Pumpkin (tabu-tabu)

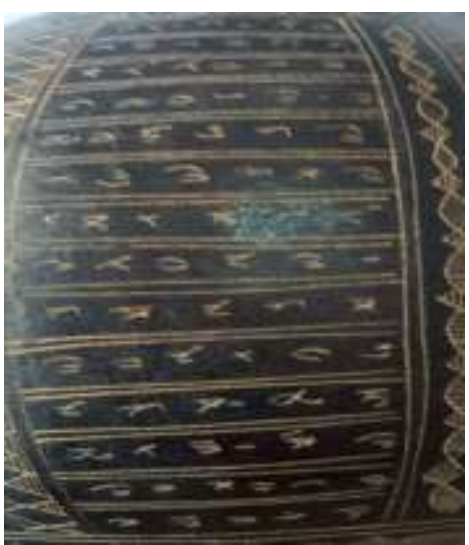

Figure 18.

Taboo as a media

\begin{tabular}{|c|c|c|}
\hline Re-Copying & Transcription & Transliteration \\
\hline 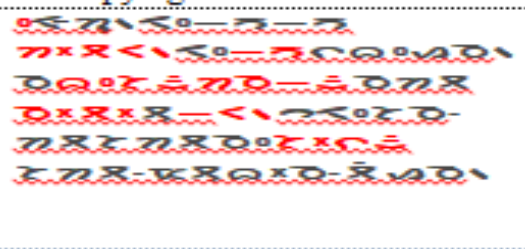 & $\begin{array}{l}\text { juil di para-para } \\
\text { botang di parlabian } \\
\text { na bisuk nampuena hata } \\
\text { na ote tu panggadisan } \\
\text { sahat-sabat ni solus } \\
\text { sahat ma tu bentean }\end{array}$ & $\begin{array}{l}\text { Fibers above the attic } \\
\text { Rattan in sun dying } \\
\text { The smart one becomes an } \\
\text { employer } \\
\text { The stupid one becomes a } \\
\text { helper } \\
\text { Arrived the boat } \\
\text { Get yo the dock }\end{array}$ \\
\hline
\end{tabular}

irror explanation:

\begin{tabular}{|c|c|}
\hline Writen text & That should \\
\hline 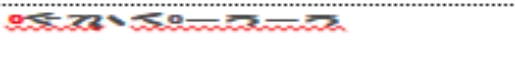 & $\begin{array}{l}\text { 1. Using the parent letter } /=7 \text { not the child letter } \gamma \\
0 / \text {, so the correct form is: }=53 \text { - (jijus) }\end{array}$ \\
\hline 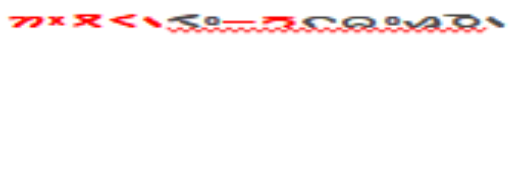 & 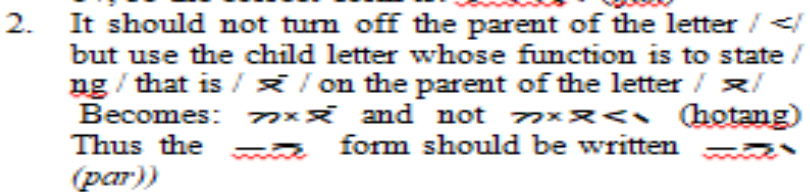 \\
\hline 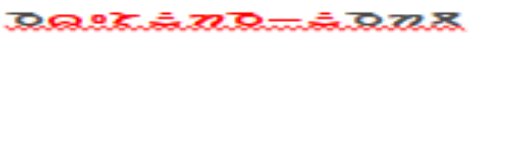 & 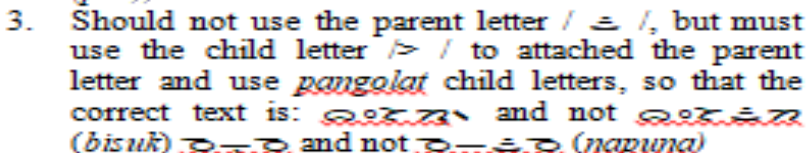 \\
\hline 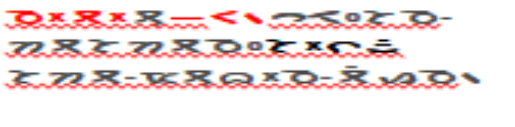 & $\begin{array}{l}\text { 4. Should not use the child letter } / \mathrm{x} / \text { to declare } / 0 / \text {, } \\
\text { but must be accompanied by the parent letter } / \mathrm{a} / \\
\text { plus the child letter } / \mathrm{x} / \text {, and the correct form is: } \\
\text { nogete and not note (na Qte) }\end{array}$ \\
\hline
\end{tabular}




\subsection{Local Wisdom in Batak Text}

The Batak people (Toba) have a lot of local wisdom. Local wisdom is a local cultural value that can be used to regulate the order of people's lives wisely (Sibarani, 2012: 113). This local wisdom is a manifestation of the way of thinking of ancient Batak ethnic. Until now, local wisdom still exists and is relevant to be applied and passed on to the young generation. Re-copying pustaha laklak is one of the activities to revitalize the local wisdom that exists in the Toba Batak community.

Based on the analysis of some of the references above, it can be seen that the text contained in the manuscript is about medicine, shamanism, determination of days and months (perhalaan), and rhyme advice (umpasa). Referring to the local wisdom described by Sibarani (2012: 135) which includes peace in the form of: politeness, honesty, social solidarity, harmony, conflict resolution, commitment, positive thoughts, and gratitude, and welfare includes: hard work, discipline, education, health, mutual assistance, gender management, cultural preservation and creativity, and environmental care, the local wisdom that can be described based on the above data is as follows.

1. Solidarity and Mutual Assistance

In the text disclosed obedience to the provisions of the day and month when going to start a job, whether done individually or in groups. Activities tend to be carried out collectively (such as: building houses, hunting, planting rice in the fields, and parties). This activity requires solidarity and mutual cooperation to bring about peace in the collective.

2. Harmony and Conflict Resolution

Through the text it can be seen that in an effort to ward off disease or withcraft from other parties, the community groups jointly the rituals and prepare all the materials needed for the ceremony. In the text the steps that must be carried out along with the ingredients that must be prepared. Based on the text it is known that in general conflicts occur not between community members in one of the collective but with another collective.

3. Cultural Preservation and Creativity

Batak manuscripts, especially containing medicines, are inherited from ancestors which are still suitable to be applied today. Even the alternative medicine that uses herbs as a media is an excellent treatment besides medical treatment. The certain diseases, such as witchcraft, cannot be resolved through medical treatment. This will be treated with herbs and the role of the datu. That matter to write down the names of diseases and ingredients for this treatment are carried out so that the next generation can apply them to everyday life. For the predecessors (ancestors) have realized a form of local wisdom that reads, "Nilangka tu jolo, sinarihan tu pudi". The meaning is, at this time the generation must continue to think as the next generation, as did by previous ancestors pass down the knowledge to their children and grandchildren.

4. Education

Batak manuscripts contain the elements of education, one of them is a war strategy. War activities always follow with the provisions in parhalaan and if violated, then likely will get a disaster. Therefore, everyone must obey the advice of the predecessors (ancestors), as expressed in the Batak proverb, "Tinallik bulung sihupi, pinarsaong bulung sihala. Unang Sumolsol tu pudi ndada sipasingot soada." The meaning is, don't regret later because you have been advised before. A lot of teaching delivered through Batak texts to be guided in life. Batak Manuscript is a handwriting that stores various expressions of thoughts and feelings as a result of the old of national culture (Hasjim, 1985: 54). Therefore, the proper for the public is to be able to read and understand the mandate that delivered in the text of the lustic literature. 


\subsection{Reproduction of Manuscripts for Commercial Interest}

Samosir Regency as one of the regencies in North Sumatra and in the middle of Lake Toba, is a very potential area and rich of the natural tourism. A very beautiful nature tour becomes an asset that can be used as a source of livelihood for the local community. The district government continues to organize the existing natural attractions so that tourists continue to arrive to this place, both of local and foreign tourists. Local people can take the advantage of this situation by working as tour guides, lake transportation, and the of other tourism services. The community is trying to produce very interesting souvenir products, so every visitor who comes will buy these souvenir products as souvenirs.

Many kinds of souvenir products that are traded in the Tomok and Tuktuk areas, Samosir Regency are in the form of: carvings, ulos (cloth) as the basic of material for making shirts and others, traditional musical instruments, and various other trinkets. However, based on the field observation, souvenir products using Batak letters are only limited to the types of products as stated above. Manuscripts as one of the cultural products that have a fantastic selling price, do not even have a standard price.

\section{Conclusion}

In general the characters used in the pustaha laklak can be read, although some words in the manuscript are difficult to interpret because they are already arkhais or words that are only commonly used by datu (shamans). Every pustaha laklak is always equipped with eight directions of the compass, the calendar, and the moon, which called parhalaan.

The Batak Manuscript is a handwriting that holds the various expressions of thoughts and feelings as a result of the old national culture. Therefore, for certain purposes, the texts will be copied again. To be able to see the authenticity of the text in the text it is necessary to do reconstruction (Robson, 1994: 16). It is proper for the public to be able to read and understand the message conveyed in the text of the pustaha laklak.

Manuscripts, especially in pustaha laklak are always copied again (reproduction). Every writing of a manuscript, the writer refers to the manuscript that becomes the reference. The copying process is done according to the request of the buyer or individual who needs it. Based on the analysis of the text of the practice that is used as the object of research, it was found that the author also made mistakes in writing. Errors tend to occur when using child letters and parent letters, especially for child letters / i / and / $\mathrm{u} /$.

Local wisdom which pictured in the Batak texts, especially the pustaha laklak and bamboo and bone which are used as objects of this research are about solidarity, mutual cooperation, harmony, conflict resolution, preservation, and cultural creativity, and loaded with educational elements. All of the local wisdom expected to be able to bring the peace and prosperity for the predecessors (ancestors) and for future generations.

\section{References}

Djamaris, Edward. 2002. Metode Penelitian Filologi. Jakarta: CV Manasco Sitanggang, JP. 2008. Raja Na Pogos. Institute of Batakology, Yayasan LPB3-Indonesia. Siahaan, Nalom. 1982. Adat Dalihat Natolu Prinsip dan Pelaksanaannya. Jakarta. Warneck, J. 2012. Kamus Batak Toba-Indonesia. Medan: Bina Media Perintis Baried, Baroroh,dkk.1994. Pengantar Teori Filologi. BPPF. Yogyakarta.

Tambunan, E.H. 1982. Sekelumit Mengenai Masyarakat Batak Toba dan Kebudayaannya Sebagai Sarana Pembangunan. Bandung: Tarsito. 
Sibarani, Robert. 2012. Kearifan Lokal, Hakikat, Peran, dan Metode Tradisi Lisan. Jakarta: Asosiasi Tradisi Lisan.

Robson, S.O. 1994. Prinsip-prinsip Filologi Indonesia. Jakarta: Pusat Pembinaan dan Pengembangan Bahasa.

Kozok, Uli. 1999. Warisan Leluhur Sastra Lama dan Aksara Batak. Jakarta: EFEO dan Kepustakaan Populer Gramedia.

. 2009. Surat Batak. Sejarah Perkembangan Tulisan Batak Berikut Pedoman Menulis Aksara Batak dan Cap Si Singamangaraja XII. Jakarta: EFEO dan Kepustakaan Populer Gramedia.

Sinaga, Djasmen Maruli Tua (Budayawan). 2006. Surat Batak Menuju Surat Indonesia. Medan: Sumatera Utara.

Tim Penyusun Kamus Pusat Pembinaan dan Perkembangan Bahasa. 1994. Kamus Besar Bahasa Indonesia Pusat Bahasa Edisi Kedua. Jakarta: Departemen Pendidikan dan Kebudayaan dan Balai Pustaka.

Tambunan, E.H. 1982. Sekelumit Mengenai Masyarakat Batak Toba dan Kebudayaannya Sebagai Sarana Pembangunan. Bandung: Tarsito. 